Egyptian Journal of Archaeological and Restoration Studies
An international peer-reviewed journal published bi-annually
www.ejars.sohag-univ.edu.eg

Original article

\title{
NEWLY DISCOVERED NORTH ARABIAN INSCRIPTIONS FROM JORDAN
}

\author{
Al-Jbour, Kh. ${ }^{(1)}$ \& Alzoubi, M. ${ }^{(2)}$ \\ ${ }^{1}$ Archaeology dept., Faculty of Tourism and Archaeology, Jordan Univ., Amman, Jordan. \\ ${ }^{2}$ Cultural Resources Management dept., Queen Rania Faculty of Tourism and Heritage, \\ Hashemite Univ., Zarqa, Jordan \\ E-mail address: k.jbour@ju.edu.jo>
}

\begin{tabular}{|c|c|}
\hline Article info. & EJARS - Vol. 11 (2) - Dec. 2021: 265-270 \\
\hline $\begin{array}{l}\text { Keywords: } \\
\text { Islamic Inscriptions } \\
\text { Safaitic Inscriptions } \\
\text { Early Arabian } \\
\text { Bādiya of Jordan } \\
\text { North Arabian }\end{array}$ & $\begin{array}{l}\text { Abstract: } \\
\text { This study deals with a new group of Ancient North Arabian } \\
\text { (Harrat Belād Ash Shām zone) inscriptions that collected during } \\
\text { a recent survey in the North Eastern Bādiya of Jordan known by } \\
\text { (Harrat Belād Ash Shām). This concerns three Pre-lslamic Safaitic } \\
\text { inscriptions, and two early Islamic texts. The purpose of this } \\
\text { article is to publish images of the newly-found inscriptions, give } \\
\text { a translation, and provide some commentary. This work was } \\
\text { achieved through } 4 \text { main points; field survey, lab works, doc- } \\
\text { umenting and tracing the collected inscriptions, and, theoretical } \\
\text { works including translating and analyzing. Our results proved } \\
\text { that Islamic inscriptions show the extent of development in } \\
\text { writing the simple Kufic script and the ability of the people of the } \\
\text { desert to learn }\end{array}$ \\
\hline
\end{tabular}

\section{Introduction}

The North Eastern Bādiya of Jordan or Harrat Belād Ash Shām is a massive zone spreading over a wide area extending from the Jordanian-Syrian border in northeastern Jordan to Saudi Arabia boarders to the south and eastward Iraqi boarders. This zone covers an area of basalt hundreds of square $\mathrm{km}$. [1]. This area, covered with grass and scrub vegetation, is extensively used for pasture by nomadic and semi nomadic herders. It is one of the main neighborhood of the Jordanian Bādiya, located to the east of Al-Safawi village north-east of Jordan, in the two sides of the international highway connecting Amman to Baghdad. The altitude of the region is about $600 \mathrm{~m}$. above the sea level in its southern part and $650 \mathrm{~m}$. in its northern side. Most of the rocks were found on the sides or on the bottom of the valleys in the area, others on the top of the cairns in the study area.

\section{Materials and Methods}

Data were collected during an epigraphical survey at the north-eastern Badiya of Jordan. The research methodology consists of the field survey, and a lab work comprising documenting and tracing the collected inscriptions, and, finally, a theoretical work including translating and analyzing of each inscriptions has been made.

\section{Results}

The study figure out more information concerning the linguistic phenomena, social and religious lives of the people who left 
these inscriptions. In addition, the Islamic inscriptions of this study show the extent of development in writing the simple Kufic script and the ability of the people of the desert to learn.

\section{Discussion}

\subsection{The Safaitic Inscriptions}

The term Safaitc is derived from the name Safa, the black basalt desert (or Harra), the term is, however, a misnomer resulting from the initial discovery of the texts in the region in 1857. The texts frequently contain extensive genealogies that trace the lineage back to eponymous ancestors called Safaitics. Their written inscriptions can be dated roughly between the $1^{\text {st }}$ century BC and the $4^{\text {th }}$ century AD. [2]. The majority existence of the Safaitic inscriptions are between the northern Syria and the middle of Euphrates in the east; Palestine and Jordan in the West; and Wadi as-Sarhan and the upper of Hejaz in the south. However, the main parts appear in southern Syria, northern and eastern Jordan, and northern Saudi Arabia. The immigrants were obliged to be ruled under Romanrulers at first. They were not fit and had not got ability to attack them. Therefore, the Safaites worked in the Roman army as soldiers. Thus they played an important role along the Roman territory between nomadic tribes and the Roman Empire. By this role, they protected the Roman from any tribal attacks. The Safaitic script, as well as the Thamudic and Lihyanite, were derived, according to some studies, from the so-called al-Musnad script in old South Arabia. The texts were written in different directions; from left to right and from up to down, vice versa or in a boustrophedon direction. Its alphabet represents 28 consonants.
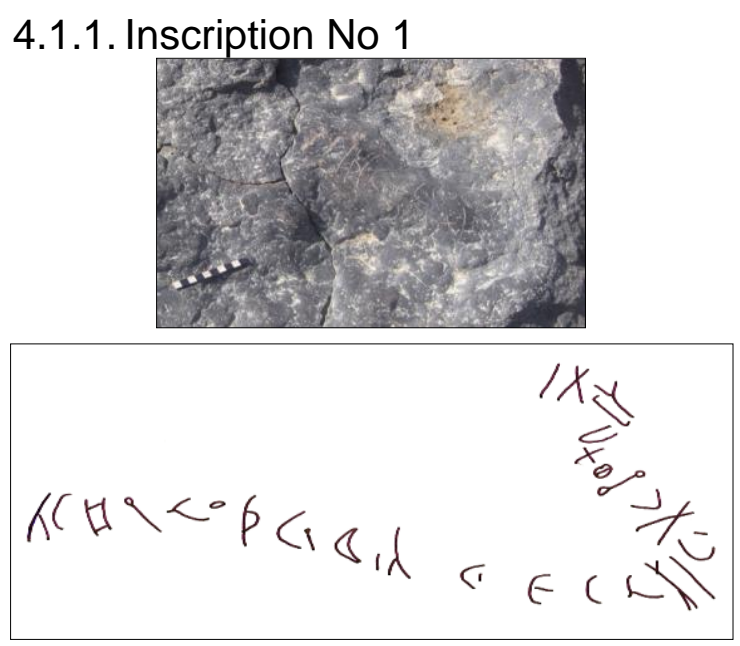

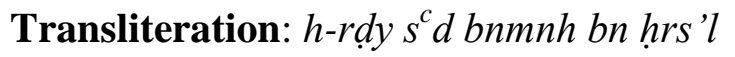
bn hbtw w-tzr h-hll

Translation: $\hat{O} R d y$ ! Help the Bnmnh son of Hrs'l son of Hbt, and he awaited the horses (or the horsemen).

\section{- Comments}

This inscription is carved on the middle of a big basalt stone. It contains an invocation for rdy to grant help for bnmnh who was waiting for the horses (or the horsemen). The inscription consists of one line started from left to right and then it bowed up at the end on the inscription. $\boldsymbol{h}-\boldsymbol{r} \boldsymbol{d y} \boldsymbol{y} \boldsymbol{h}$ is the safaitic definite article "the". $\boldsymbol{r} \boldsymbol{d} \boldsymbol{y}$ is a divinity name occurred generally in safaitic in two forms: $r d y$ and $r d w$ [3]. Accordingly to Littmann, this divinity represents the planet Venus, and he claimed also that $r d w$ is the masculine form and $r d y$ has is the feminine one [4]. $\boldsymbol{s}^{\boldsymbol{c}} \boldsymbol{d}$ : v.l-stem: "to help" derived from the root $s^{c} d$. It is the equivalent of the Arabic ساعد/sā id "grant help" [5]. mnh: a masculine personal name derived from the root $m n n$, it is the equivalent of the Arabic منة/menat means "kindness; gift". This personal name is rarely attested in Safaitic inscriptions. hrs'l: It is a masculine theophoric personal name hitherto unrecorded on other safaitic inscriptions. It consists of two element: the verb hrs "to keep watch; to look after; to anticipate" [6] and the divinity 
Name 'l. hhbt: a well-known Safaitic personal name derived from the root $h b \underline{t}$ carries the meaning "worthless, wicked, impure person". It could parallel to tradition name Habī $\underline{i}$ [7]. $\boldsymbol{w}-\boldsymbol{t z} \boldsymbol{r}: \boldsymbol{w}$-: it is a common conjunction in Semitic "and". $\boldsymbol{t} \boldsymbol{z} \boldsymbol{r}$ : v.t2-stem. "to wait, to await; to lie in wait" it derived from the root: $n z r . \boldsymbol{h}-\boldsymbol{h l}$ : It is a concrete noun preceding by the definite article $-h$ "the horses $r$ the horsemen [8].

\subsubsection{Inscription No 2}
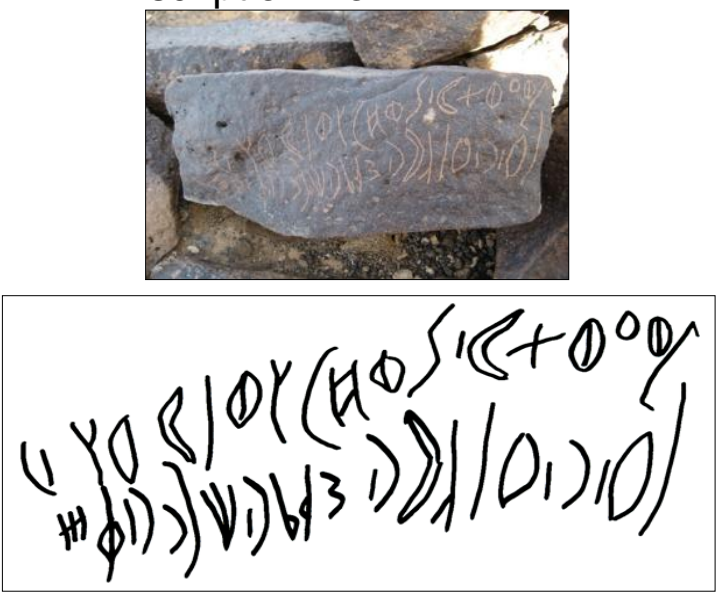

Transliteration: ljn bn jlhm bn šdy bn hrb bn qțbn h-jml w-hrdw gnmt $w-{ }^{c} w r$

Translation: By jn son of jlhm son of $\breve{s} d y$ son of hrb son of qtbn this Camel, $\hat{O}$ Rad w (grant) booty and obliterate (who damage the text).

\section{- Comments}

This inscription is written in a medium size basalt stone in a so-called boustrophedon form. The inscription consists of two lines carefully executed in medium pecked out letters, apparently, with a sharp tool. Its letters go from left to right and then reverse for the next line. $j \boldsymbol{n}$ : is a personal name frequently attested in safaitic inscriptions. It could be the equivalent of the Arabic جَنَّijanna; name derived from the root جنं/janana means "Take away power of judgment; to cover completely or hide from view" [9]. Jlhm: a well-known personal name in safaitic and in Nabataean (as : jlhmw). It is the equivalent of the Arabic personal name جلهم/Jalham means "the great stone" [10]. šdy: Personal name frequent in safaitic, it is derived from the root šdy meaning "chanting". hrb: p.n. $\mathrm{m}$. frequently attested in Safaitic, Thamudic, Lihyanite, Sabaic, Minaean and in Qatabanian [1]. It is the equivalent of the Arabic حرب /harb 'war'; name derived from the root /حَرَبَ sonal name is rarely mentioned in other safaituic inscriptions, it has been noted once in [13]. $\boldsymbol{g}$ nmt: n.m.f. "booty". It is could be vocalized as Arabic غَ/ganìmat; name derived from the root torious, obtain goods". cwr: n.s.m. "Blindness" derived from the root ${ }^{c} w r$ "to blind".

\subsubsection{Inscription No 3}
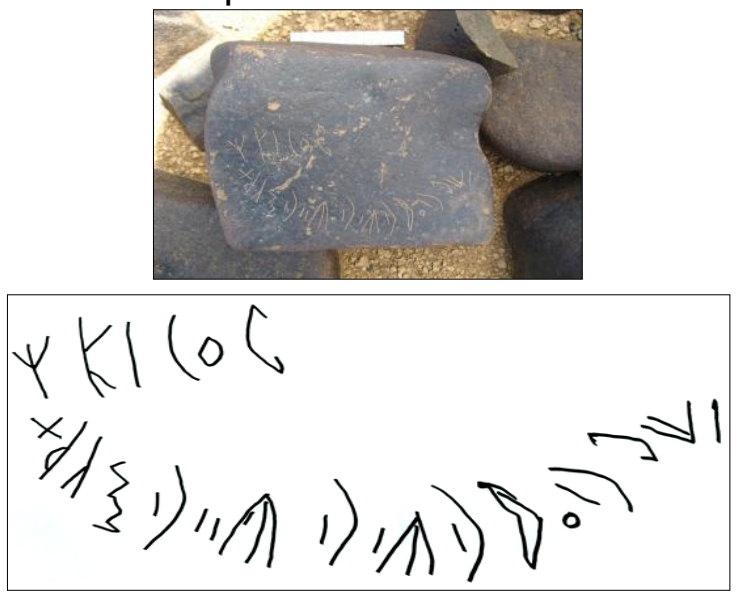

Transliteration: $\operatorname{lhr} b n^{c} m$ bn hnn bn ḥnn bn šhdt d’ $l b^{c} r$

Translation: $B y$ hr son of ${ }^{c} m$ son of $h n$ son of hnn son of shdt from the tribe of $b^{c} r$

\section{- Comment}

This inscription is found on a small size basalt stone. It is carved by a sharp tool, the letters of the inscription are thin and of large size the inscription was written from right to left in curved form. The inscription contains only the author's name and his affiliation. $\boldsymbol{h r}$ : a well-known masculine personal name. It has been noted in Safaitic and in Thamudic, and in Lihyanite [14]. It could 
be the equivalent of the Arabic hur "free, unrestricted" [15]. ' $m$ : personal name frequently attested in safaitic and in thamudic. It could be vocalized as "amam "perfect, entire". It might be also the equivalent of the Arabic "am/عَ "uncle". hn: a personal name derived from the root hnn "long for; strive for ": šhdt: a well-known Safaitic personal name derived from the root šhd [16]. $d$ 'l: ḍ. pro. relative pronoun. ' $l$ : n. col. "lineage; people". This word probably reflects an original collective noun based on the root ' $w l$, ' $\bar{a} l$. The term is sometimes used to refer to anybody of people, including outside groups such as the Nabataeans, Jews, and Romans [17]. $\boldsymbol{b}^{\boldsymbol{c}} \boldsymbol{r}$ : this tribe has been mentioned in four other safaitic inscriptions from al Juthoum in the Badia of Jordan and al Zalef in Syria [18].

\subsection{The Islamic Inscriptions}

Hundreds new Early Islamic inscriptions have been found in the Northeastern Badia of Jordan in the last two decades, they belong to the Ayyubid, Mamluk, Umayyad and Abbasside periods. These inscriptions vary in subjects and contents, most of them are prayers in favor of deceased, and other contains Qur'anic verses Hadith and few reveal historical events happened in the region.

\subsubsection{Inscription 4}

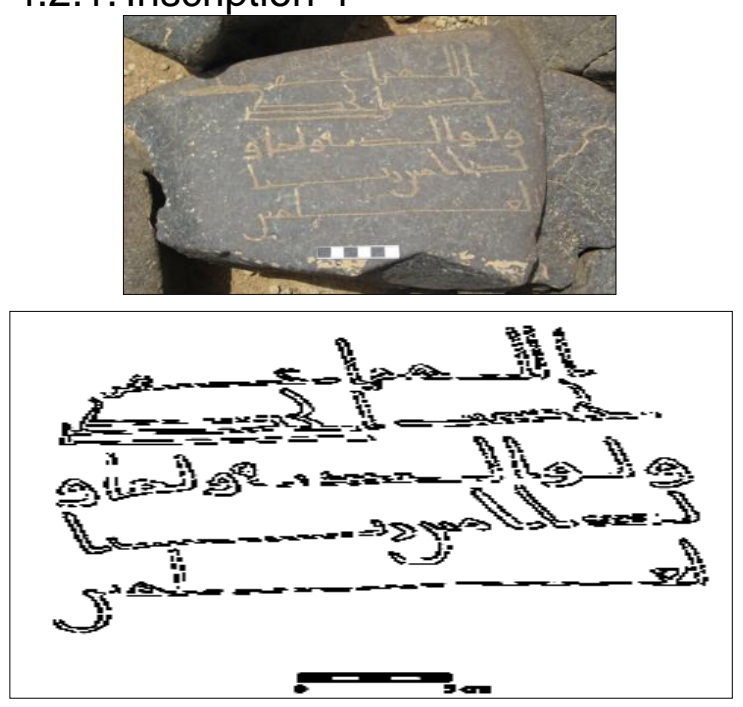

Arabic reading

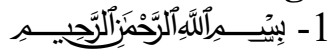

2- 2- اللهم اغفر

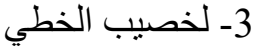

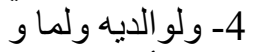

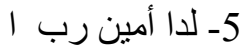

6- لعلمين

Transliteration

1- bi-smi llāhi l-rahmāni l-rahīm

2- allāhumma ighfir

3-l-Hasīb al-Hațì.

4-w-l-waledaih $w$-lima $w$

5- lada āmīn rabbu

6- l- 'àlamīn

Translation

1- In the name of God.

2. Ô God, forgive

3. Hasīb al-Hatī.

4- and for his parents and their

5- offspring [lit. what they have begotten]

Amen! Lord of

6- the world!

\section{- Comments}

This inscription was written in middle of a small basalt stone; it consists of six lines and was written in simple Kufic script free of punctuation. It was carved on an elongated basalt rock measuring about $32 . \mathrm{cm}$ in width and $38 \mathrm{~cm}$. in height. The inscription started with the basmalah (in the mane of Allāh) which is sloppily written, followed by a praying in favor of Hasīb bin al-Hațī. The text has no date, based on the form of the letter; it seems to be dated back to the second century AH. The text is characterrized by its way of writing; the leaving out of vowels as in the word العلمين, the decreasing of the spaces between lines and the division of the words between two line as in (ولما، والعالمين), but also the writing of the $y a$ in the bowed form. The proper name Hasīb was a well-known personal name during the different Islamic periods. According to Ibn Manzur, the tribe name is known in Oman and Bahrain al-Hați one of the frequent personal name, Ibn Manzur 
mention that a famous type of spears was attributed al-Hațî tribe [19]. A famous Issa bin Fatek al-Hați was is one of the Kharijites in the Umayyad period who had a meeting with Al-Zubayr bin Al-Awwam [20].

\subsubsection{Inscription 5}
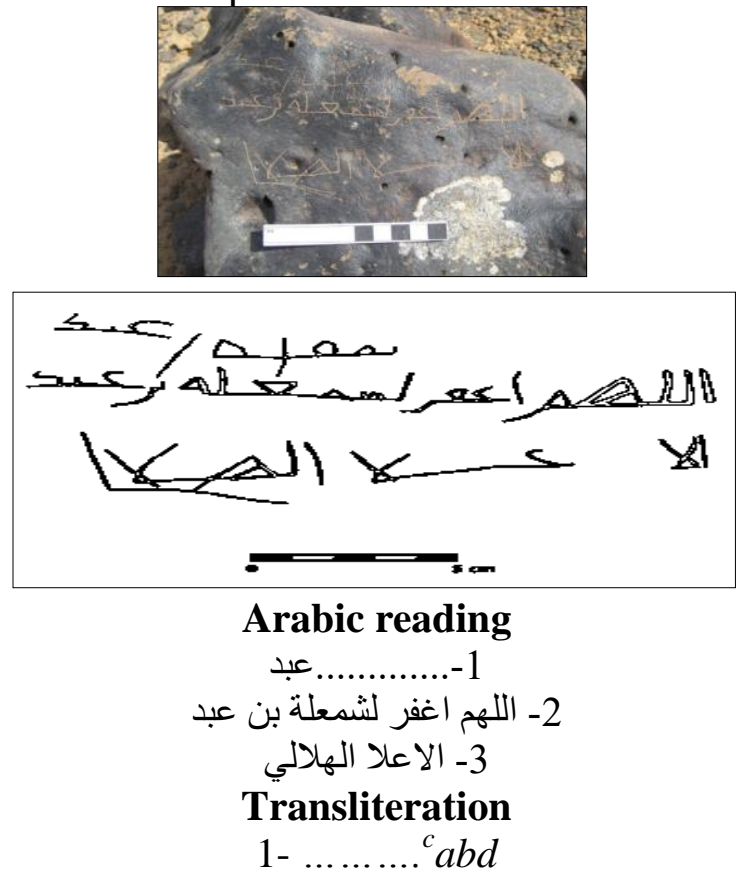

2- allāhumma ighhfir l-ŠSam ${ }^{c}$ alat bin ${ }^{c}$ abd

3- ala ${ }^{c} \overline{l a}$ al Hilālī

Translation

$1-\ldots \ldots . . . .^{c} a b d$

2- $\hat{O}$ God, forgive Šam ${ }^{c}$ alat son of ${ }^{c}$ abd

3- ala ${ }^{c}$ là al Hilālì

\section{- Comments}

The importance of this short inscriptions comes out from the rare propre names that appearted in the inscriptions. We have only one example in the historical resources for the mention of the perosonal name $\breve{S}^{2} m^{c}$ alat, this come from the Umayyad period during the reign of the caliph Abdelaziz ibn Al-Walid ibn Abd al-Malik ; a poet called $\breve{S}^{2} m^{c}$ alat was mentioned in al-Balādhurī book Ansab al-Ashraf [21]. The personal name ${ }^{c} A b d$ al $A^{c} l \bar{a}$ is a well-kown name in the classical Arab. It consists of two elements: ${ }^{c} A b d$ : "the servant" and the god (Allāh) most Beautiful names) al Aclāalالأعلى "the Highest".
Regarding the Trib's name of $\check{S}^{\prime} \mathrm{m}^{c}$ alat, which is al Hilālì, is one of the very famouse ancient Arabian tribe [22]. Therefore, the lineages mentioned in the two inscriptions indicate the importance of the Jordanian Badia in the diversity of the proportions of people living in it from different Arab tribes during the early Islamic periods, in addition to its importance as transit areas for many pilgrimage or trade caravans through different paths in light of the availability of water in the region.

\section{Conclusion}

These inscriptions have been presented here in transcription, and facsimile together with a discussion of a number of points which have been arisen from their study. Moreover, the study managed to figure out more information about the linguistic phenomena, social and religious lives of the people who left these inscriptions. It figures out more information about the linguistic, social and religious aspects about the people who left these inscriptions

\section{References}

[1] Oxtoby, W. (1968). Some inscriptions of the Safaitic Bedouin, American Oriental Society, New Haven.

[2] Al Maani, S. \& Alzoubi, M. (2017). New Safaitic inscriptions from al ${ }^{\mathrm{c}}$ Awshaji al Janoubi-Northeastern Bādyia of Jordan, Adumatu, Vol. 36. pp. 19-30.

[3] Online Corpus of the Inscriptions of Ancient North Arabia, Oxford Univ., London. https://krc.web.ox.ac.uk/article/ ociana (8-6-2021)

[4] Littmann, E. (1940). Thamūd und Safāa. Studien zur alt nordarabischen inschriften kunde, F. Brockhaus Leipzig.

[5] Al-Jallad, A. \& Jaworska, K. (2019). A dictionary of the Safaitic inscriptions, Brill, Leiden.

[6] Alzoubi, M. (2013). New Safaitic inscriptions from Ghadir Abū Țarfa/ Jordan, Acta Orientalia Academiae Scientiarum Hungaricae, Vol. 66 (4), pp. 417-425 
[7] Caskel, W. (1966). Ğamharat an-nasab: Das genealogische Werk des Hišām bin Muḥammad al-Kalbī, Bd. II. Brill, Leiden.

[8] Alzoubi, M. \& Al Maani, S. (2018). Some new Safaitic inscriptions from Dhuweila - Jordan, Adumatu, Vol. 37, pp. 7-16.

[9] Ibn Manzur, M., (2003). Lisān al- 'Arab (Arab tung), Dar Șader,. Beirut

[10] Al Harạ̣sheh, R. (2010). Nuquš Șafaeyah jadydah men al-badyyah alUrdunyyah (New Safaitic Inscriptions from Badia in), Ward Books, Amman.

[11] Ababneh, M. (2005). Neue Safaitische Inschriften und deren bildliche Darstellungen. Shaker Verlag, Aachen.

[12]Ibn Duraid, M. (1991). Al-Ishtiqāq, edt. Abd al-Salām Hārun (Derivation), Dar el Jūl, Beirut.

[13] Winnett, F. \& Harding, L. (1978). Inscriptions from fifty Safaitic cairns, Univ. of Toronto Press, Toronto.

[14] Harding, L., (1971). An index and concordance of Pre-Islamic Arabian names and inscriptions, University of Toronto, Toronto.

[15] Alzoubi, M. \& Al-Qudrah, H. (2014). New Safaitic inscriptions from the Har- oun region in Northeast Jordan, Acta Orientalia Academiae Scientiarum Hungaricae, Vol. 67 (3), pp. 259-272.

[16] Al-Rawabdeh, N. \& Al-Husan, A. (2016). New ancient North Arabian inscriptions with references to Nabataea, Adumatu, Vol. 33. pp. 7-12

[17] Khrayshen, F. (1995). New Safaitic inscriptions from Jordan, Syria. Archéologie, Art et Histoire, Vol. 72 (3-4). pp. 401414.

[18] Al-Roussan, M. (1992). Al-Qaba'el alTamudyyah $w$ al-Safawyyah (Thamudic and Safaitic Tribes), King Saud Univ., Riyadh.

[19] Al-Jbour., Kh. (1998). Arabic inscriptions from Wada Salmà, SHAJ, Vol. 7, pp. 673-697.

[20]Al-Balādhurī, A., (1936). Ansab AlAshraf (Genealogies of the Nobles), Hebrew University, Press Jerusalem.

[21]Ibn al Atheer, M. (1980). Al-Kamil fi al-Tarikh, (The Complete History), Dār al Kitāb Alcarab̄̄, Beirut.

[22] Meyers, M., (1997). The Oxford encyclopedia of archaeology in the Near East, Oxford Univ. Press, UK. 